\title{
Robotic radical prostatectomy: analysis of midterm pathologic and oncologic outcomes: A historical series from a high-volume center
}

\author{
Anastasios D. Asimakopoulos ${ }^{1,2}$ (1) · Filippo Annino ${ }^{1,3}$. Camille Mugnier ${ }^{1}$. Laurent Lopez ${ }^{1}$. Jean Luc Hoepffner ${ }^{1}$. \\ Richard Gaston ${ }^{1} \cdot$ Thierry Piechaud $^{1}$
}

Received: 13 July 2020 / Accepted: 15 November 2020 / Published online: 7 December 2020

(C) The Author(s) 2020

\begin{abstract}
Background Identifying predictors of positive surgical margins (PSM) and biochemical recurrence (BCR) after radical prostatectomy (RP) may assist clinicians in formulating prognosis. Aim of the study was to report the midterm oncologic outcomes, to identify the risk factors for PSM and BCR and assess the impact of the PSM on BCR-free survival following robot-assisted laparoscopic radical prostatectomy (RALP).

Methods From 2005 to 2010, 1679 consecutive patients underwent transperitoneal RALP. Data was retrospectively collected by an independent statistical company and analyzed in 2014. Median postoperative follow-up was 33.5 mo. BCR was defined as any detectable serum prostate-specific antigen (PSA) $\geq 0.2 \mathrm{ng} / \mathrm{mL}$ in two consecutive measurements. BCR-free survival was estimated using the Kaplan-Meier method. Univariate and multivariate analysis were applied to identify risk factors for PSM and BCR.

Results In pN0/pNx cancers, pathologic stage was pT2 in 1186 patients (71.8\%), pT3 in 455 patients (27.6\%), and pT4 in 11 patients (0.6\%). PSM rate was $17.4 \%$ and $36.9 \%$ of pT2 and pT3 cancers, respectively. Pathologic Gleason score was $<7,=7$ and $>7$ in $42.1 \%, 53 \%$ and $4.9 \%$ of the patients, respectively. Overall BCR-free survival was $73.1 \%$ at 5 years; the 5 -year BCR-free survival was $87.9 \%$ for pT2 with negative surgical margins. PSA, Gleason score (both bioptic and pathologic), pathologic stage (pT) and surgeon's volume were significant independent predictors of PSM. PSA, pathologic Gleason score, pT and PSM were significant independent predictors of BCR-free survival. Seminal vesicle-sparing, nerve-sparing approach and the extent of nerve-sparing (intra vs interfascial dissection) did not negatively affect margin status or BCR rates.

Conclusions PSMs are a predictor of BCR. Being the only modifiable factor influencing the PSM rate, surgical experience is confirmed as a key factor for high-quality oncologic outcomes.
\end{abstract}

Keywords Cancer of prostate $\cdot$ Robotics $\cdot$ Prostatectomy $\cdot$ Laparoscopy $\cdot$ Positive surgical margin

Despite the current, conflicting evidence regarding the benefit of radical prostatectomy (RP) over deferred treatment in both the overall and cancer-specific survival of patients affected by localized prostate cancer (PCa), RP still remains a mainstay of treatment [1]. Robot-assisted laparoscopic RP

Anastasios D. Asimakopoulos

tasospao2003@yahoo.com

1 Department of Urology, Clinique Saint Augustin, Bordeaux, France

2 Department of Surgical Sciences, Unit of Urology, Fondazione PTV Policlinico Tor Vergata, Rome, Italy

3 Unit of Urology, Ospedale San Donato, Arezzo, Italy
(RALP) has become the established state-of-the-art surgical treatment for $\mathrm{PCa}$ [2].

Although many patients are disease-free after surgery, nearly $30 \%$ [3] of patients experience biochemical recurrence (BCR). Defined as a detectable prostate-specific antigen (PSA) level following RP in the absence of clinical progression, $\mathrm{BCR}$ is the most common pattern of disease relapse [4]. Patients with BCR have a considerably worse prognosis, often develop metastasis, and can die of the disease [3, 4]. Therefore, identifying prognostic predictors of $\mathrm{BCR}$ after RP to assist clinicians in predicting outcomes for decision-making is required. Moreover, although positive surgical margin (PSM) is frequently reported in RP series, their clinical relevance remains uncertain despite extensive investigation. Several studies demonstrated an association 
between PSM and BCR [5-7], while others have observed insignificant or even contrary correlations [8-10].

Aim of this study was to report the midterm oncologic outcomes, to identify the risk factors for PSM and BCR and assess the impact of the PSM on BCR-free survival following RALP.

\section{Materials and methods}

From January 2005 to June 20101679 consecutive patients underwent RALP for localized PCa at our department. All data was retrospectively collected into a customized database and analyzed by an independent statistical company in 2014.

All RALP were performed transperitoneally with an antegrade approach through the Retzius space by four laparoscopic urologists. No frozen sections were routinely obtained. When indicated, a nerve-sparing procedure and/or standard lymph node dissection was performed. In patients who did not undergo lymph node dissection, cancer was classified as pNx. The degree of nerve-sparing was decided on the basis of preoperative variables (PSA level, clinical stage, Gleason score, $\%$ and location of positive biopsies, $\%$ of involvement of the single bioptic cores, preoperative potency status as well as data of the magnetic resonance of the prostate -when available-) and intraoperative findings (visual cues such as changes in color or texture of the tissue, capsular flaps, bulging and surface irregularities, adhesiveness of planes or presence of the mass effect produced by the tumor). Periprostatic arteries or veins were not used as landmarks for the dissection.

History of previous abdominal, pelvic or prostatic surgery were not contraindications for RALP. Patients who had received neoadjuvant therapy or adjuvant therapy before PSA relapse were excluded from analyses.

The study was conducted in accordance with Good Clinical Practice rules and with the ethical principles contained in the Declaration of Helsinki as amended in Hong Kong. Each patient gave written informed consent, while the study protocol obtained regulatory ethical committee notification (PTV trials register 138.10). Baseline demographic and clinical characteristics of the patients (age, BMI, preoperative PSA, prostate volume, etc.) as well as all medical and surgical complications occurring both in inpatient and outpatient settings were recorded [11]. Prostatectomy specimens were analyzed for weight, pathologic stage, Gleason's grade, tumor location, margin status (positivity, location and extension).

The methods of processing the specimen have been previously described [12]. Briefly, the RALP specimens were cut into $5 \mathrm{~mm}$ axial sections, formalin-fixed and routinely processed for paraffin embedding. Subsequently the embedded specimens were cut into $5 \mu \mathrm{m}$ sections and stained with haematoxylin and eosin. A PSM was reported if cancer cells were found at the inked specimen margin.

PSA data were collected every 4 months in the first year, then every 6 months for two years and then yearly. BCR was defined as two consecutive PSA rises $\geq 0.2 \mathrm{ng} / \mathrm{ml}$ [13]. The BCR-free survival was estimated using the Kaplan-Meier method. Survival curves were stratified by PSA level, pathologic features, surgical margins status, pathological stage and pathological stage/surgical margins. Pathologic Gleason score was divided as follows: Gleason score $<7,=7$, or $>7$. PSA level was considered a qualitative variable as follows: $\mathrm{PSA}<10 \mathrm{ng} / \mathrm{ml}$ or $\geq 10 \mathrm{ng} / \mathrm{ml}$. The curves were compared using the log-rank test.

The risk factors for PSM (prevalence, localization, extension), BCR, early (within 2 years) or late BCR (after 2 years following RALP) were tested using univariate analysis and subsequently confirmed using a logistic regression model.

Young men with several risk factors for clinical failure (high pathologic Gleason score, multiple or extended PSM) were submitted to adjuvant radiotherapy. Instead, patients $>70$ years or with an isolated focal PSM and otherwise low-risk organ-confined PCa close monitoring with serial PSA measurements was recommended, with radiotherapy at the earliest sign of recurring disease, if any.

A double-sided $p$ value $<0.05$ was considered statistically significant. All data were analyzed using SAS V9.3.

\section{Results}

Median postoperative follow-up was 33.5 mo $(\mathrm{Q} 1: \mathrm{Q} 3=12.1: 54.2)$. Mean age was 61.5 years $(\mathrm{SD} 6.4)$ and mean preoperative PSA $7.37 \mathrm{ng} / \mathrm{ml}$ (SD 3.76). The majority of the patients (63\%) were affected by T1c PCa, mainly of Gleason score $6(3+3)(75 \%) .37 \%$ of the patients had received previous abdominal surgery and $2.7 \%$ previous prostatic surgery. Hypertension was the main comorbidity $(29 \%$ of the patients). The baseline characteristics of the patients are summarized in Table 1.

Mean operative time was 221 (SD 55.8) minutes, while mean console time was $117 \mathrm{~min}$ (SD 43.5). In the majority of the cases (89.2\%) an interfascial dissection of the periprostatic neural network was performed. In the $33.9 \%$ of the cases a seminal vesicle-sparing approach was performed, while a running suture was mainly adopted for the vesicourethral anastomosis with no posterior reconstruction of the Denonvillier's fascia. Operative time, type of dissection, estimated blood loss, hospital stay, length of catheterization as well as the major intra and perioperative complications are summarized in Table 2.

Pathologic data and main oncologic outcomes are summarized in Table 3. Mean prostate weight was $44.4 \pm 18.7$ 
Table 1 Demographic and preoperative clinical data and major comorbidities

\begin{tabular}{|c|c|c|}
\hline Variable & Outcome & $\begin{array}{l}\text { Number of patients } \\
\text { with available data } \\
(\%)\end{array}$ \\
\hline Number of patients & 1679 & \\
\hline Mean age, years (SD) & $61.5(6.4)$ & $1675(99.8 \%)$ \\
\hline Mean preoperative PSA, ng/ml (SD) & $7.37(3.76)$ & $1322(78.74 \%)$ \\
\hline Clinical Gleason score, mean (SD) & $6.2(0.6)$ & $1365(81.3 \%)$ \\
\hline Prevalence of clinical Gleason score $(\%)$ & & $1365(81.3 \%)$ \\
\hline$\leq 6$ & 75 & \\
\hline 7 & 21.9 & \\
\hline $8-10$ & 3.1 & \\
\hline Clinical stage (\%) & & $1360(81 \%)$ \\
\hline cT1 & 63 & \\
\hline cT2 & 31 & \\
\hline cT3 & 6 & \\
\hline \multicolumn{3}{|l|}{ Major comorbidities (\%) } \\
\hline Morbid obesity & 0.4 & $1659(98.8 \%)$ \\
\hline Hypertension & 29.2 & $1665(99.2 \%)$ \\
\hline Diabetes mellitus & 2.5 & $1651(98.3 \%)$ \\
\hline Coronary artery disease & 5.1 & $1658(98.7 \%)$ \\
\hline Myocardial infarction & 1.7 & $1648(98.2 \%)$ \\
\hline Chronic kidney failure & 0.2 & $1659(98.8 \%)$ \\
\hline Peripheral vascular disease & 3.6 & $1654(98.5 \%)$ \\
\hline Mean preoperative hemoglobin, gr/dl (SD) & $15.1(1.1)$ & $1360(81 \%)$ \\
\hline Previous abdominal surgery, overall (\%) & 37.1 & $1653(98.5 \%)$ \\
\hline \multicolumn{3}{|l|}{ Main previous surgical procedures } \\
\hline Appendectomy (\%) & 53.4 & \\
\hline Inguinal hernia repair (\%) & 24.6 & \\
\hline Colon resection $(\%)$ & 2.3 & \\
\hline Other $(\%)$ & 19.7 & \\
\hline
\end{tabular}

Number of evaluated patients for each variable is presented. PSA prostate-specific antigen, $S D$ standard deviation gr. In $\mathrm{pN} 0 / \mathrm{pNx}$ cancers, postoperative stage was pT2a in 128 patients $(7.8 \%)$, pT2b in 21 patients $(1.3 \%)$, pT2c in 1037 patients $(63.2 \%)$, pT3a in 357 patients $(21.7 \%)$, pT3b in 98 patients $(6 \%)$ and pT4 in 1 patient $(0.1 \%)$. Pathologic Gleason score was $3+3$ in $42.1 \%$ and $3+4$ in $42.4 \%$ of the patients. In $12.3 \%$ of the patients a capsular incision was identified in the pathologic examination.

Overall PSM rate was 375/1657 (22.6\%). Margin rate per stage was $17.4 \%$ and $36.9 \%$ of pT2 and pT3 cancers, respectively. PSM were mainly localized at the level of the apex with a similar distribution for both lobes as shown in Table 4.

$1312 / 1679$ patients $(78.1 \%)$ received at least one followup visit. 203/1312 patients experienced BCR during followup (15.5\%). The BCR-free survival (BCRFS) at 12, 24, 48 and 60 months after RALP were 94.6\%, 91.2\%, 79.3\% and $73.1 \%$, respectively (Fig. 1).
The 5-year BCRFS was $71.6 \%$ for PSA $<10 \mathrm{ng} / \mathrm{ml}$ and $61.8 \%$ for a PSA $>10 \mathrm{ng} / \mathrm{ml}$. The relative survival curves were statistically different (Fig. 2, $p=0.003$ ).

According to Gleason score, difference between survival curves also reached significance $(p<0.0001)$. Patients with a Gleason score $<7$ had a 5-year BCRFS of $88.7 \%$ compared with $61.5 \%$ for those with Gleason score $=7$ and with $57.6 \%$ of those with Gleason score $>7$ (Fig. 3).

Surgical margin status was a predictor of PSA recurrence by the log-rank test (Fig. 4). 5-year BCRFS for patients with negative surgical margins was $78.2 \%$ compared to $59.7 \%$ for patients with PSM $(p<0.0001)$.

According to the pathologic stage, 5-year BCRFS was $84 \%$ for pT2c vs $54.1 \%$ for pT3a and $41.8 \%$ for pT $3 b$ $(p<0.0001)$. Pathologic stage was a predictor of PSA recurrence by the log-rank test (Fig. 5).

When analysis was stratified by pathologic stage and margin status, the 5-year BCR-free survival rate was $87.9 \%$ for pT2 with negative surgical margins. Cases of pT2 with PSM 
Table 2 Intra and perioperative data

\begin{tabular}{lll}
\hline Variable & Outcome & $\begin{array}{l}\text { Number of patients } \\
\text { with available data } \\
(\%)\end{array}$ \\
\hline Mean operative time (OR occupancy, minutes) (SD) & $221.2(55.8)$ & $1633(97.26 \%)$ \\
Mean console time, minutes (SD) & $117.6(43.5)$ & $1543(91.9 \%)$ \\
Mean skin to skin time, minutes (SD) & $148.8(43.6)$ & $1600(95.3 \%)$ \\
Intrafascial dissection & $10.1 \%$ & $1649(98.2 \%)$ \\
Interfascial dissection & $89.2 \%$ & \\
Extrafascial dissection & $0.7 \%$ & $1667(99.3 \%)$ \\
Seminal vesicle-sparing & $33.9 \%$ & $1639(97.6 \%)$ \\
Running urethrovesical anastomosis & $97.5 \%$ & $1679(100 \%)$ \\
Lymphadenectomy & 132 pts \\
Intraoperative complications & & \\
Severe bleeding & 0.4 & $1679(100 \%)$ \\
Rectal injury $*(\%)$ & 0.1 & $1659(98.8 \%$ \\
Conversion to pure laparoscopy (\%) & 0.5 & $1634(73.5 \%)$ \\
Robot failure (\%) & 0.6 & $1679(98.1 \%)$ \\
Perioperative complications & & \\
Hemorrhage**(\%) & 1.3 & \\
Clot retention-bladder tamponade***(\%) & 2.2 & \\
Anastomotic urine leak****\%) & 0.2 & \\
Blood transfusion (\%) & 3.5 & \\
Febrile urinary tract infection $(\%)$ & 15 & \\
Ileal lesion (\%) & 0.1 & \\
Obstructive ileum****(\%) & 0.2 & \\
Mean hospital stay, days (SD) & $5.4(2.6)$ & \\
Mean catheterization time, days (SD) & $7.5(2.6)$ & \\
\hline & & \\
\end{tabular}

Actual number of patients with available data is shown. OR operating room, $S D$ standard deviation

Intraoperative complications were managed as follows:

*Intraoperative suture without further sequelae

**Laparoscopic reintervention and assessment of the haemostasis

***Endoscopic clot evacuation and bladder irrigation

$* * * *$ Prolonged catheterization

*****Open abdominal surgery and pT3a with negative surgical margins were characterized by similar 5-yr progression-free survivals rates $(69 \%$ and 57.4\%, respectively, $\mathrm{p}=0.34$ ) (Fig. 6).

At the univariate analysis (chi ${ }^{2}$ or $\mathrm{t}$-Student), preoperative PSA $\geq 10(p=0.01)$, preoperative Gleason score $(p=0.02)$, lower specimen weight (mean non-PSM 45.7 \pm 18.93 , mean PSM $39.8 \pm 16.21, p<0.0001$ ), higher pathologic stage or pathologic Gleason score and lower surgeon volume were the possible predictive factors of PSMs, while the previous prostatic or abdominal surgery, the type of NVB dissection (extra vs intra vs interfascial) and the conservation of the tip of the seminal vesicles were not associated with PSM (Table 5). At the multivariate analysis the preoperative PSA $\geq 10 \mathrm{ng} / \mathrm{ml}$, the pT3 stage, the preoperative Gleason score $>7$ or the pathologic Gleason score $\geq 7$ as well as a surgeon's volume $<100$ cases per year were confirmed as predictive factors for PSM (Table 6). No factor was identified in the univariate analysis that could predict the location or the extent of the PSM.

Factors predicting biochemical recurrence in the univariate model were the presence and location of the positive surgical margins, the pathologic stage and pathologic Gleason score, the non-seminal vesicle-sparing technique and the infraction of the prostate capsule during surgery (Table 7). The multivariate analysis confirmed that only the PSM and the higher pathologic stage and Gleason score were predictive of BCR (Table 8), while the seminal vesicle-sparing does not increase BCR rates. No factor predictive of an early ( $\leq 2$ years) versus late ( $>2$ years) BCR at univariate analysis was confirmed at the multivariate analysis.

$324 / 1364$ patients (23.8\%) received at least one secondary treatment among radiotherapy $(210 / 324,64.8 \%)$, hormonal 
Table 3 Oncologic outcomes

\begin{tabular}{lll}
\hline Variable & Outcome & $\begin{array}{l}\text { Number of patients } \\
\text { with available data } \\
(\%)\end{array}$ \\
\hline $\begin{array}{l}\text { Pathologic stage (\%) } \\
\text { pT2a }\end{array}$ & $1642(97.8 \%)$ \\
pT2b & 7.8 & \\
pT2c & 1.3 & \\
pT3a & 63.2 & \\
pT3b & 21.7 & \\
pT4 & 6 & $1612(96 \%)$ \\
Capsule violation \% & 0.1 & $1654(98.5 \%)$ \\
Mean prostate weight, gr (SD) & 12.3 & \\
Mean pathologic Gleason score & $64.4(18.7)(0.63)$ & $1652(98.4 \%)$ \\
(SD)\% & & \\
$\leq 6$ & 42.1 & \\
7 & 53 & $1364(81.2 \%)$ \\
8-10 & 4.9 & \\
Positive surgical margins \%* & 22.6 & \\
PSM/pT\% & & \\
pT2 & 17.4 & \\
pT3 & 36.9 & \\
Biochemical recurrence \%** & 15.5 & \\
Secondary treatment & 23.8 & \\
(adjuvant/salvage RT or HT) \%** & & \\
\hline A $6.7 \%)$ \\
\hline
\end{tabular}

Actual number of patients with available data is shown. $S D$ standard deviation, $g r$ grams, $P S M$ positive surgical margins, $R T$ radiotherapy, $H T$ hormone-therapy

Table 4 Overall distribution of the positive surgical margins (PSM) per lobe

\begin{tabular}{lll}
\hline PSM location & Left & Right \\
\hline Apex focal & 84 & 95 \\
Apex extensive & 18 & 16 \\
Posterolateral focal & 36 & 28 \\
Posterolateral extensive & 10 & 9 \\
Base focal & 29 & 27 \\
Base extensive & 7 & 11 \\
Bladder neck focal & 1 & 2 \\
Bladder neck extensive & 1 & 1 \\
Overall & 186 & 189 \\
& $375 / 1657$ (missing values: 22$)$ \\
\hline
\end{tabular}

Length of PSM was defined as focal or extensive. Focal PSM: single PSM $(\mathrm{sPSM}) \leq 3 \mathrm{~mm}$;-Extensive PSM: sPSM with linear length $>3 \mathrm{~mm}$ or several margins regardless of the length

treatment $(154 / 324,47.5 \%)$ and chemotherapy $(1 / 324$, $0.3 \%)$.

\section{Discussion}

Identifying factors that predict the incidence of PSM and/ or BCR may help physicians to adequately inform patients who are more likely to receive adjuvant multimodal therapy following RP.

PSMs after RP are generally considered an adverse outcome associated with failure of the surgery to achieve cure of $\mathrm{PCa}$, tumor recurrences and debilitating additional therapies [14]. In the current era of the RALP, the prevalence of the PSMs ranges between $6.5 \%$ and $32 \%$, with a mean value of $15 \%$ [15]. The distribution of the PSMs per pathologic stage varies between series, with a mean PSM rate of $9 \%$ in pT2 cancer (range $4-23 \%), 37 \%$ in pT3 (29-50\%) and $50 \%$ in pT4 cancers (40-75\%) [15]. In our study, although regarding the outcomes of a historical series, both the overall PSM rate (22.6\%) and the PSM/pT rate was conform to the published literature.

Several studies identified clinical and pathologic factors predicting PSM most of which cannot be altered by the treating physician. Ficarra et al. [16] reported that prostate volume and cT stage were the only clinical variables predictive of any PSM, whereas pT stage was the unique pathologic predictor. In another study, patient's body mass index (BMI), PSA level, pT stage and prostate volumes (all $p$ values $<0.001$ ) were independent predictors of any PSM, whereas Gleason score was not. Similarly, BMI, PSA and prostate volume were predictors of PSMs in pT2 cancers [17]. In our series, multivariate Cox model showed that PSA, Gleason score (both bioptic and pathologic), pathologic stage (pT) and surgeon's volume below 100 cases/year were significant independent predictors of PSM. In the univariate analysis no factor that could predict the location or the extent of the PSM was identified.

Regarding BCR rates Badani et al., in the first study of large-scale oncological outcomes after RALP, reported a BCR rate of $7.3 \%$ in 2766 patients undergoing RALP at a median follow-up of 22 months. In that study, no detailed analysis of predictors of BCR was undertaken [18]. Menon et al. reported a $13.6 \%$ probability of BCR at 5 years for 1384 patients submitted to RALP [19]. Sukumar S et al. report a $81 \%$ of BCR-free survival at 8 years after RALP [20]. Murphy et al. reported on 400 patients with a BCR-free survival of $87 \%$ at a median follow-up of 22 months [21] while Suardi et al. reported 3- and 5-year BCR-free survival rates of $94 \%$ and $86 \%$ in 184 patients with a minimum follow-up of 5 years [22]. Sooriakumaran et al. reported a BCR-free survival rate of $84.8 \%$ at a median follow-up of 6.3 years [7], while Liss et al. reported a $84.9 \%$ at 5 years [23]. More recently, Diaz M et al. reported 10-year oncologic data on 483 patients that were submitted to RALP; 10-year BCR-free survival was $73.1 \%$ [24]. 
Fig. 1 Biochemical progressionfree survival. 367 observations with invalid time or censoring values were deleted

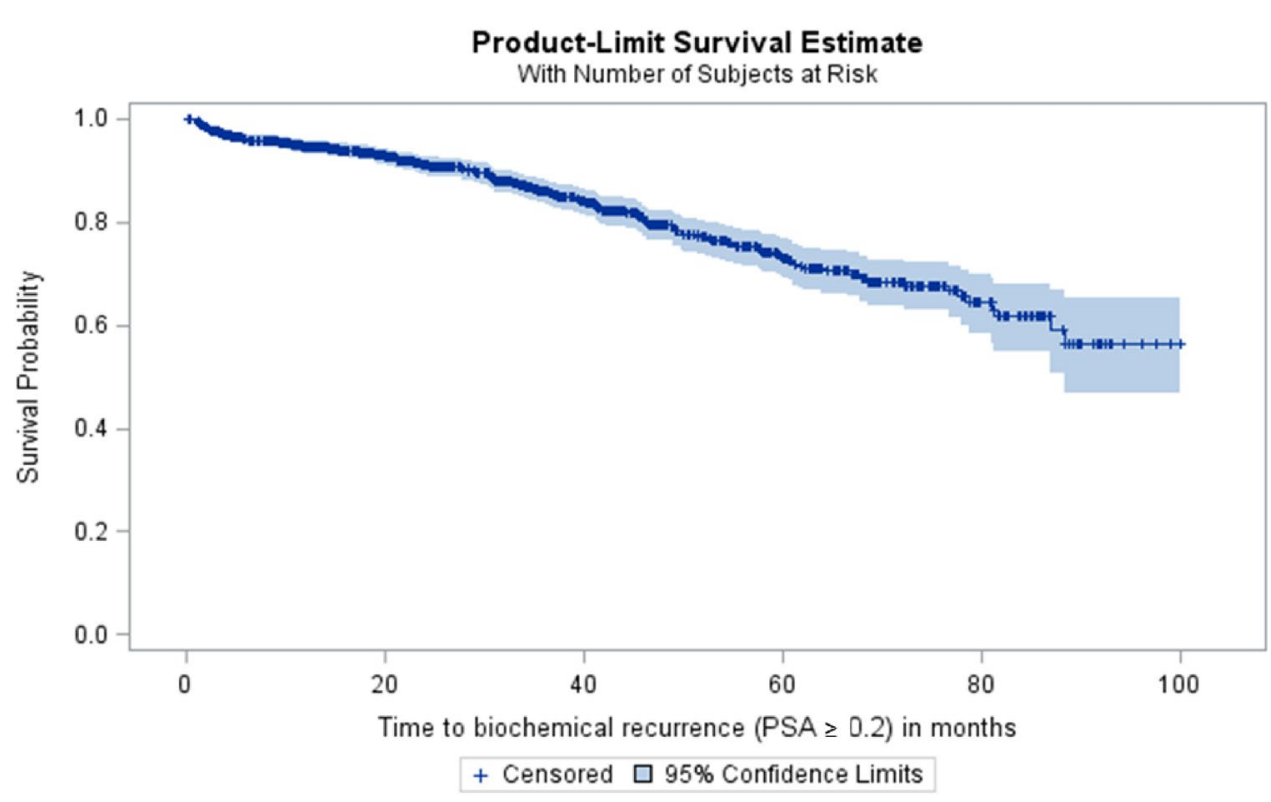

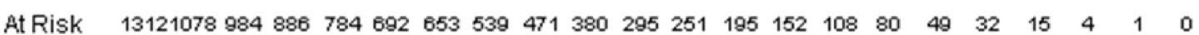

\begin{tabular}{l|l|c}
\hline \hline Parameter & Statistics & $\begin{array}{c}\text { Total } \\
\text { (N=1679) }\end{array}$ \\
\hline $\begin{array}{l}\text { Number of patients } \\
\text { Biochemical recurrence (PSA } \geq 0.2)\end{array}$ & $n(\%)$ & $203(15.47 \%)$ \\
Censored & $n(\%)$ & $1109(84.53 \%)$ \\
& Filled $n(\%)$ & $1312(78.14 \%)$ \\
& Missing $n(\%)$ & $367(21.86 \%)$ \\
\hline BCR-free survival at & & $94.64[93.19 ; 95.79]$ \\
12 months & $\%[95 \%$ Cl] & $91.15[89.23 ; 92.74]$ \\
24 months & $\%[95 \%$ Cl] & $79.30[76.04 ; 82.17]$ \\
48 months & $\%[95 \%$ Cl] & $73.07[69.02 ; 76.68]$ \\
60 months & $\%[95 \%$ Cl] &
\end{tabular}

In our study $15.5 \%$ of patients experienced BCR during follow-up. The BCR-free survival (BCRFS) at 12, 24, 48 and 60 months after RALP were $94.6 \%, 91.2 \%, 79.3 \%$ and $73.1 \%$, respectively. The multivariate analysis confirmed that the locally-advanced disease (pT3 stage), the pathologic Gleason score $\geq 4+3$ and the PSM were predictive of BCR. The first two factors are immutable and are manifestations of the biology of the disease; the last one is partially influenced by the surgeon's volume, highlighting the role of the surgeon who, as an independent predictor of outcome, can affect the prognosis ensuring better local control. Although the effects of PSM on the risk of BCR are still unclear in the published literature, our study suggests that PSM represent an independent risk factor for BCR and as shown, their rate is function of the surgeon's experience. Location of the margins, pathologic stage and extent of dissection of the periprostatic neuronal network were not predictive of BCR. No factor predictive of an early ( $\leq 2$ years) versus late $(>2$ years) BCR at univariate analysis was identified at the multivariate analysis.

Other recent studies assessed the relationship between surgical experience and oncologic outcomes of RALP, demonstrating that greater surgeon experience was associated with a lower probability of PSM [25]. Being the only modifiable factor influencing the PSM rate in our study, surgical experience is confirmed as a key factor for high-quality oncologic outcomes. The low rate of the PSM of this historical series that conforms to the most recent RALP series suggests that previous surgeon's experience, even with different surgical approaches to RP (open, laparoscopic) may also be at the basis of high-quality oncologic outcomes. 
Fig. 2 Biochemical progression-free survival according to preoperative PSA

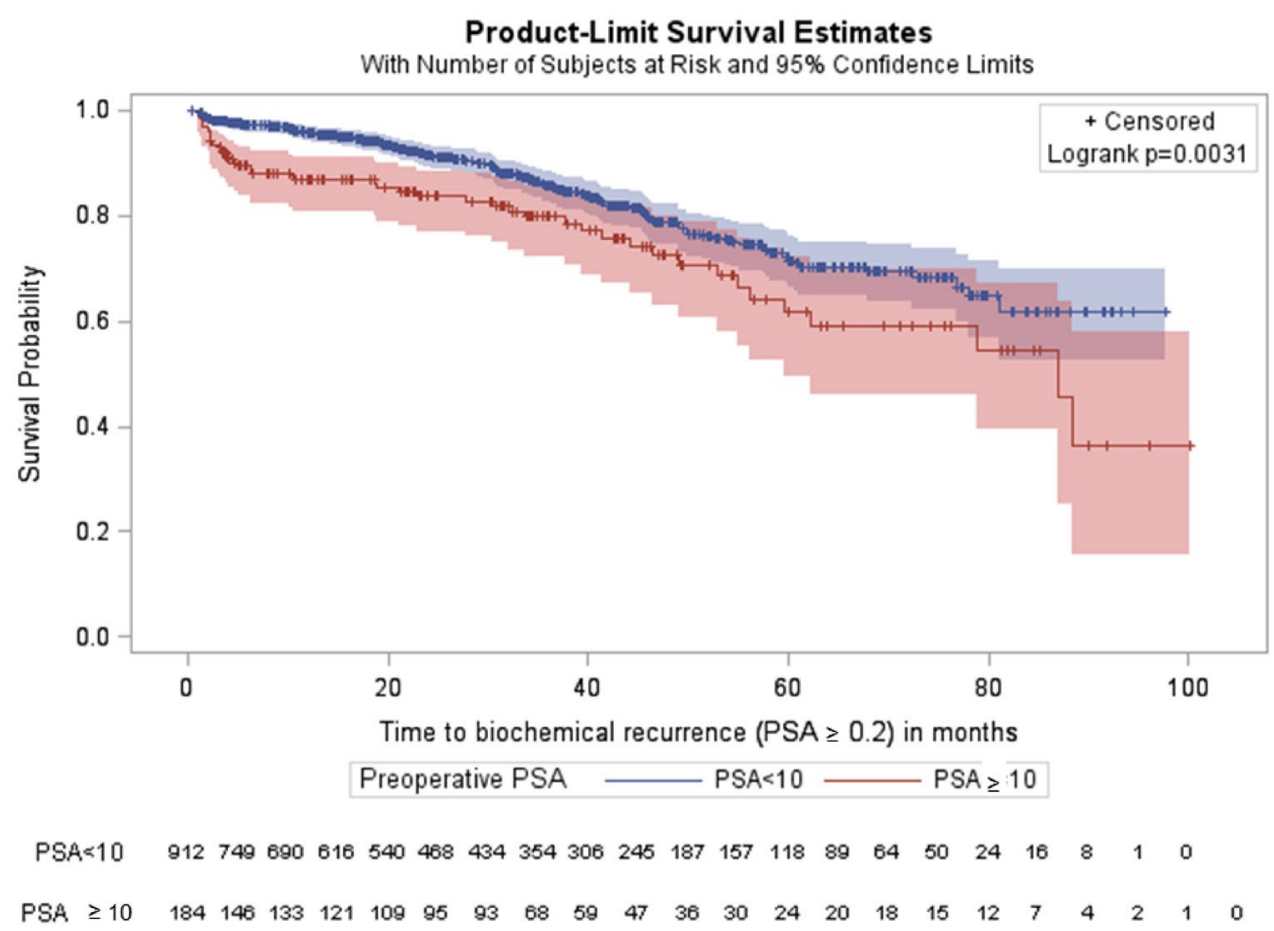

Biochemical recurrence (BCR) free survival according to preoperative PSA

\begin{tabular}{|c|c|c|c|c|}
\hline \multirow[t]{2}{*}{ Parameter } & \multirow[t]{2}{*}{ Statistics } & \multicolumn{2}{|c|}{ Preoperative PSA } & \multirow{2}{*}{$\begin{array}{c}\text { Total } \\
(N=1322 *)\end{array}$} \\
\hline & & $\begin{array}{c}P S A<10 \\
(N=1092)\end{array}$ & $\begin{array}{l}P S A \geq 10 \\
(N=230)\end{array}$ & \\
\hline $\begin{array}{l}\text { Number of patients } \\
\text { Biochemical recurrence } \\
\text { (PSA } \geq 0.2) \\
\text { Censored }\end{array}$ & $\begin{array}{l}n(\%) \\
n(\%) \\
\text { Filled } n(\%) \\
\text { Missing } n(\%)\end{array}$ & $\begin{array}{l}132(14.47 \%) \\
780(85.53 \%) \\
912(83.52 \%) \\
180(16.48 \%)\end{array}$ & $\begin{array}{c}45(24.46 \%) \\
139(75.54 \%) \\
184(80.00 \%) \\
46(20.00 \%)\end{array}$ & $\begin{array}{c}177(16.15 \%) \\
919(83.85 \%) \\
1096(82.90 \%) \\
226(17.10 \%)\end{array}$ \\
\hline $\begin{array}{l}\text { BCR-free survival at } \\
12 \text { months } \\
24 \text { months } \\
48 \text { months } \\
60 \text { months }\end{array}$ & $\begin{array}{l}\%[95 \% \mathrm{Cl}] \\
\%[95 \% \mathrm{Cl}] \\
\%[95 \% \mathrm{Cl}] \\
\%[95 \% \mathrm{Cl}]\end{array}$ & $\begin{array}{l}95.71[94.06 ; 96.91] \\
91.46[89.07 ; 93.34] \\
78.28[74.08 ; 81.88] \\
71.62[66.37 ; 76.20]\end{array}$ & $\begin{array}{l}86.84[80.82 ; 91.07] \\
83.67[76.97 ; 88.57] \\
70.74[60.56 ; 78.74] \\
61.81[49.34 ; 72.06]\end{array}$ & \\
\hline & p-value (Log-rank) & \multicolumn{3}{|c|}{$p_{\text {log-rank }}=0.0031$} \\
\hline
\end{tabular}

* 357 patients have missing values for preoperative PSA
Institutions with smaller caseloads and more than one surgeon using the robotic device will possibly have more problems with the learning curve saturation. These centers may probably benefit of the current possibilities for intraoperative margin assessment [14]. Others suggest even the development of radical prostatectomy-only centers [26].

In fact, the lack of tactile sensation in robotic surgery leads surgeons to rely on compensatory visual strategies to overcome this handicap. As a result surgical experience, adoption of energy and tension-free dissection of the periprostatic neural network and enhanced vision in a bloodless field can compensate for the lack of tactile sensation allowing surgeons to identify correctly alarming visual cues
[27] and adapt dissection of the NVT to the actual risk of PSM.

In our technique, the accurate dissection of the neurovascular triangle as a first step of the surgery identifies all the important structures that will guide the subsequent neurovascular dissection, such as the base of the prostate, the lateral aspect of the bladder neck, the neurovascular tissue, the Denonvillier's fascia and the seminal vesicle. By this approach, a correct identification of the periprostatic fascial layers is obtained [12].

The dissection proceeds tension-free (in order to avoid creation of capsular flaps) and energy-free (in order to maintain the original color and texture of the tissues). Small arteries that leave the bundle to enter the prostate are gradually 
Fig. 3 Biochemical progression-free survival according to pathologic Gleason score

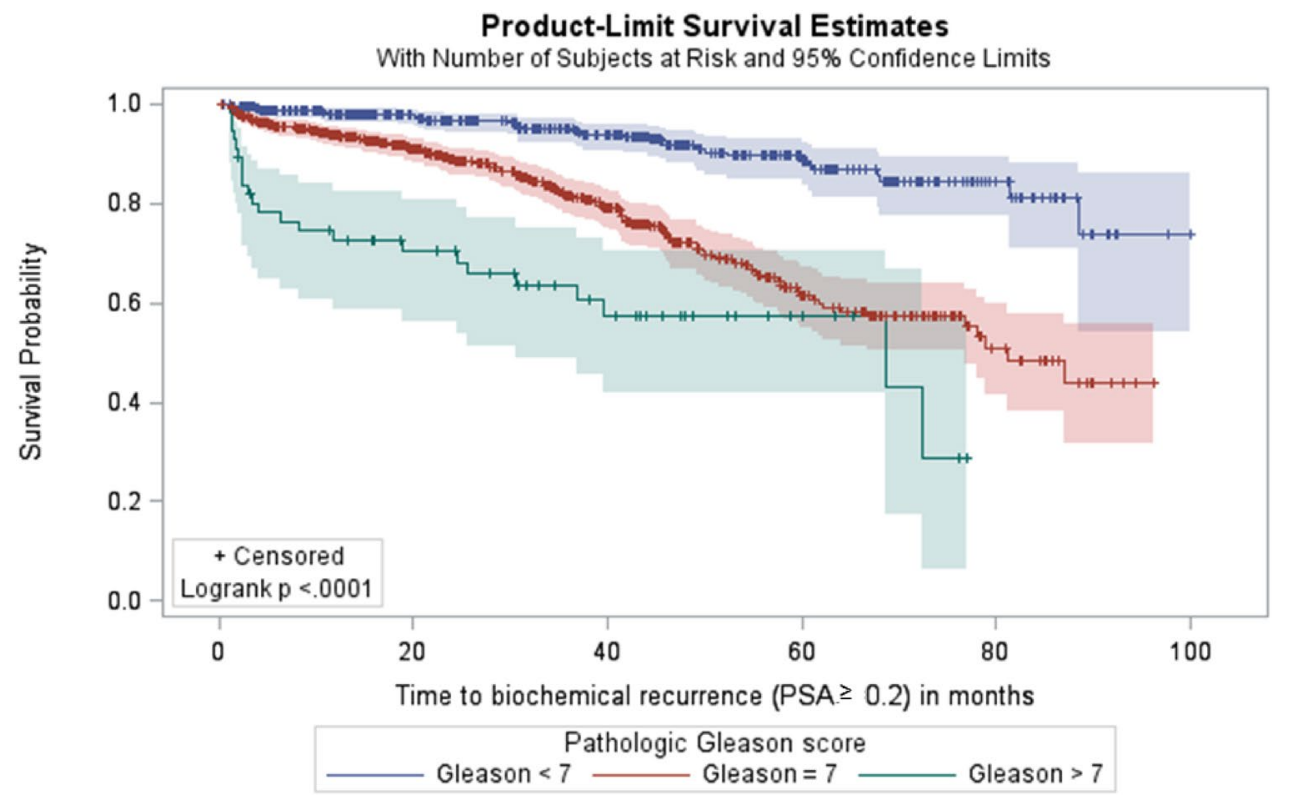

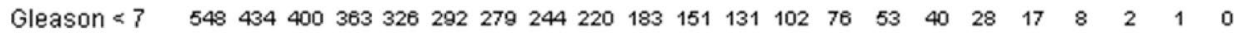

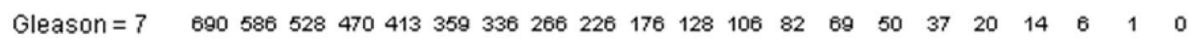

$\begin{array}{llllllllllllllllll}\text { Gleason }>7 & 56 & 42 & 40 & 37 & 33 & 30 & 28 & 22 & 19 & 15 & 11 & 9 & 7 & 5 & 3 & 2 & 0\end{array}$

Biochemical recurrence (BCR) free survival according to pathologic Gleason score

\begin{tabular}{|c|c|c|c|c|c|}
\hline \multirow[t]{2}{*}{ Parameter } & \multirow[t]{2}{*}{ Statistics } & \multicolumn{3}{|c|}{ Pathologic Gleason score } & \multirow{2}{*}{$\begin{array}{c}\text { Total } \\
\left(N=1652{ }^{*}\right)\end{array}$} \\
\hline & & $\begin{array}{c}\text { Gleason }<7 \\
(N=695)\end{array}$ & $\begin{array}{c}\text { Gleason }=7 \\
(N=876)\end{array}$ & $\begin{array}{c}\text { Gleason }>7 \\
(N=81)\end{array}$ & \\
\hline $\begin{array}{l}\text { Number of patients } \\
\text { Biochemical recurrence } \\
\text { (PSA } \geq 0.2) \\
\text { Censored }\end{array}$ & $\begin{array}{l}n(\%) \\
n(\%) \\
\text { Filled } n(\%) \\
\text { Missing } n(\%)\end{array}$ & $\begin{array}{l}36(6.57 \%) \\
512(93.43 \%) \\
548(78.85 \%) \\
147(21.15 \%) \\
\end{array}$ & $\begin{array}{l}141(20.43 \%) \\
549(79.57 \%) \\
690(78.77 \%) \\
186(21.23 \%)\end{array}$ & $\begin{array}{ll}23 & (41.07 \%) \\
33 & (58.93 \%) \\
56 & (69.14 \%) \\
25 & (30.86 \%) \\
\end{array}$ & $\begin{array}{c}200(15.46 \%) \\
1094(84.54 \%) \\
1294(78.33 \%) \\
358(21.67 \%)\end{array}$ \\
\hline $\begin{array}{l}\text { BCR-free survival at } \\
12 \text { months } \\
24 \text { months } \\
48 \text { months } \\
60 \text { months }\end{array}$ & $\begin{array}{l}\%[95 \% \mathrm{Cl}] \\
\%[95 \% \mathrm{Cl}] \\
\%[95 \% \mathrm{Cl}] \\
\%[95 \% \mathrm{Cl}]\end{array}$ & $\begin{array}{l}98.10[96.36 ; 99.01] \\
96.58[94.24 ; 97.99] \\
91.97[88.10 ; 94.62] \\
88.72[83.72 ; 92.25] \\
\end{array}$ & $\begin{array}{l}93.69[91.48 ; 95.34] \\
88.75[85.76 ; 91.14] \\
72.01[66.89 ; 76.48] \\
61.54[55.03 ; 67.40]\end{array}$ & $\begin{array}{l}72.63[58.73 ; 82.52] \\
70.50[56.35 ; 80.81] \\
57.59[41.99 ; 70.40] \\
57.59[41.99 ; 70.40]\end{array}$ & \\
\hline \multicolumn{3}{|c|}{ p-value (Log-rank) } & \multicolumn{2}{|c|}{ Plog-rank $<.0001$} & \\
\hline
\end{tabular}

* 27 patients have missing values for Gleason score identified, clipped, and divided since traction on them could cause disruption of the capsule. The bloodless planes that separate without resistance are followed and developed; we prefer to cut sharply through veins and periprostatic tissue rather than forcing a blunt dissection that is more likely to produce a capsular flap exposing to higher risk of PSM.

It finally should be underlined that seminal vesicle-sparing did not negatively affect margin status or BCR rates, as also suggested by others [28], while nor the nerve-sparing neither the grading of nerve-sparing (intra vs interfascial dissection) was associated with worse cancer outcomes both in terms of PSM or BCR, as also suggested by two recent meta-analyses [29, 30].
Our outcomes -characterizing an era without wide adoption of magnetic resonance imaging for preoperative staging- probably show that selective nerve-sparing during RARP, using only the preoperative clinical variables and surgeon's intraoperative perception seems to provide reasonable intermediate term oncologic outcomes with acceptable PSM rate.

The major limitation of our study is its retrospective design. However, an independent statistical service company acquired and processed the data, avoiding potential biases of self-processing. The study population encompass the effects of periods of transition from laparoscopy to robotics, of experimentation with the new technique, of transfer of knowledge among the team members, and 
Fig. 4 Biochemical progression-free survival according to surgical margins. $\mathrm{SM}+=$ positive surgical margins, $\mathrm{SM}-=$ negative surgical margins

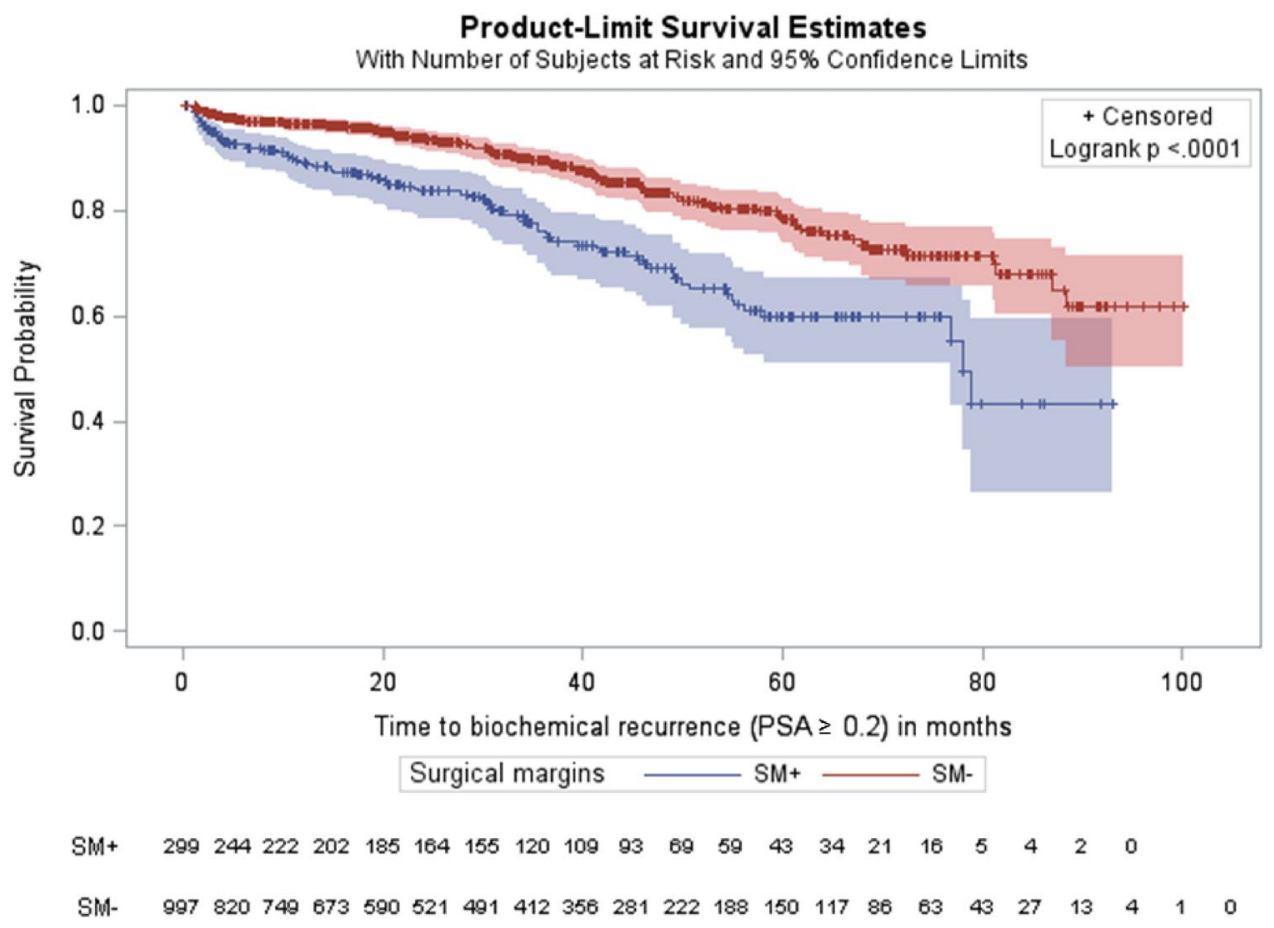

Biochemical recurrence $(B C R)$ free survival according to surgical margins

\begin{tabular}{|c|c|c|c|c|}
\hline \multirow[t]{2}{*}{ Parameter } & \multirow[t]{2}{*}{ Statistics } & \multicolumn{2}{|c|}{ Surgical margins } & \multirow{2}{*}{$\begin{array}{c}\text { Total } \\
(N=1657 *)\end{array}$} \\
\hline & & $\begin{array}{c}\text { Non positive } \\
\text { margins (SM-) } \\
(\mathrm{N}=1282)\end{array}$ & $\begin{array}{c}\text { Positive margins } \\
(\mathrm{SM}+) \\
(\mathrm{N}=\mathbf{3 7 5})\end{array}$ & \\
\hline $\begin{array}{l}\text { Number of patients } \\
\text { Biochemical recurrence }(P S A \geq 0.2)\end{array}$ & $n(\%)$ & $121(12.14 \%)$ & $77(25.75 \%)$ & $198(15.28 \%)$ \\
\hline Censored & $\begin{array}{l}n(\%) \\
\text { Filled } n(\%) \\
\text { Missing } n(\%)\end{array}$ & $\begin{array}{ll}876 & (87.86 \%) \\
997 & (77.77 \%) \\
285 & (22.23 \%) \\
\end{array}$ & $\begin{array}{c}222(74.25 \%) \\
299(79.73 \%) \\
76(20.27 \%) \\
\end{array}$ & $\begin{array}{c}1098(84.72 \%) \\
1296(78.21 \%) \\
361(21.79 \%)\end{array}$ \\
\hline $\begin{array}{l}\text { BCR-free survival at } \\
12 \text { months } \\
24 \text { months } \\
48 \text { months } \\
60 \text { months }\end{array}$ & $\begin{array}{l}\%[95 \% \mathrm{CI}] \\
\%[95 \% \mathrm{CI}] \\
\%[95 \% \mathrm{CI}] \\
\%[95 \% \mathrm{CI}]\end{array}$ & $\begin{array}{l}96.37[94.92 ; 97.41] \\
93.65[91.66 ; 95.18] \\
83.26[79.63 ; 86.30] \\
78.24[73.71 ; 82.09]\end{array}$ & $\begin{array}{l}89.11[84.76 ; 92.27] \\
83.63[78.42 ; 87.68] \\
68.99[61.29 ; 75.15] \\
59.73[51.14 ; 67.31]\end{array}$ & \\
\hline & p-value (Log-rank) & & Plog-rank $<.0001$ & \\
\hline
\end{tabular}

finally of progressive maturation. The effect of tumor location and tumor volume/maximum tumor diameter on the incidence of PSM/BCR was not evaluated. Concerning the importance of the case-volume of the surgeon on the outcomes, the study does not probably reflect the real-life, since the comparisons are performed between experts in prostatectomy and the observed differences, although statistically significant, are probably lower than the expected. However, it seems that even between experts in prostatectomy, higher surgical volume is associated to better outcomes. Finally, although oncologic outcome is best defined by cancer-specific survival, meeting such endpoint in prostate cancer requires significantly longer follow-up than that in the present study. However, the statistical analysis was performed in 2014, and consequently long-term outcomes including metastasis-free survival and overall survival are not available.

\section{Conclusions}

PSMs after RP are a predictor of biochemical recurrence and they depend on surgeon's experience. The low overall PSM and BCR rates reported in the current historical series of RALP reflects the importance of the previous surgeon's 
Fig. 5 Biochemical progression-free survival according to pathologic stage
Product-Limit Survival Estimates

With Number of Subjects at Risk and 95\% Confidence Limits

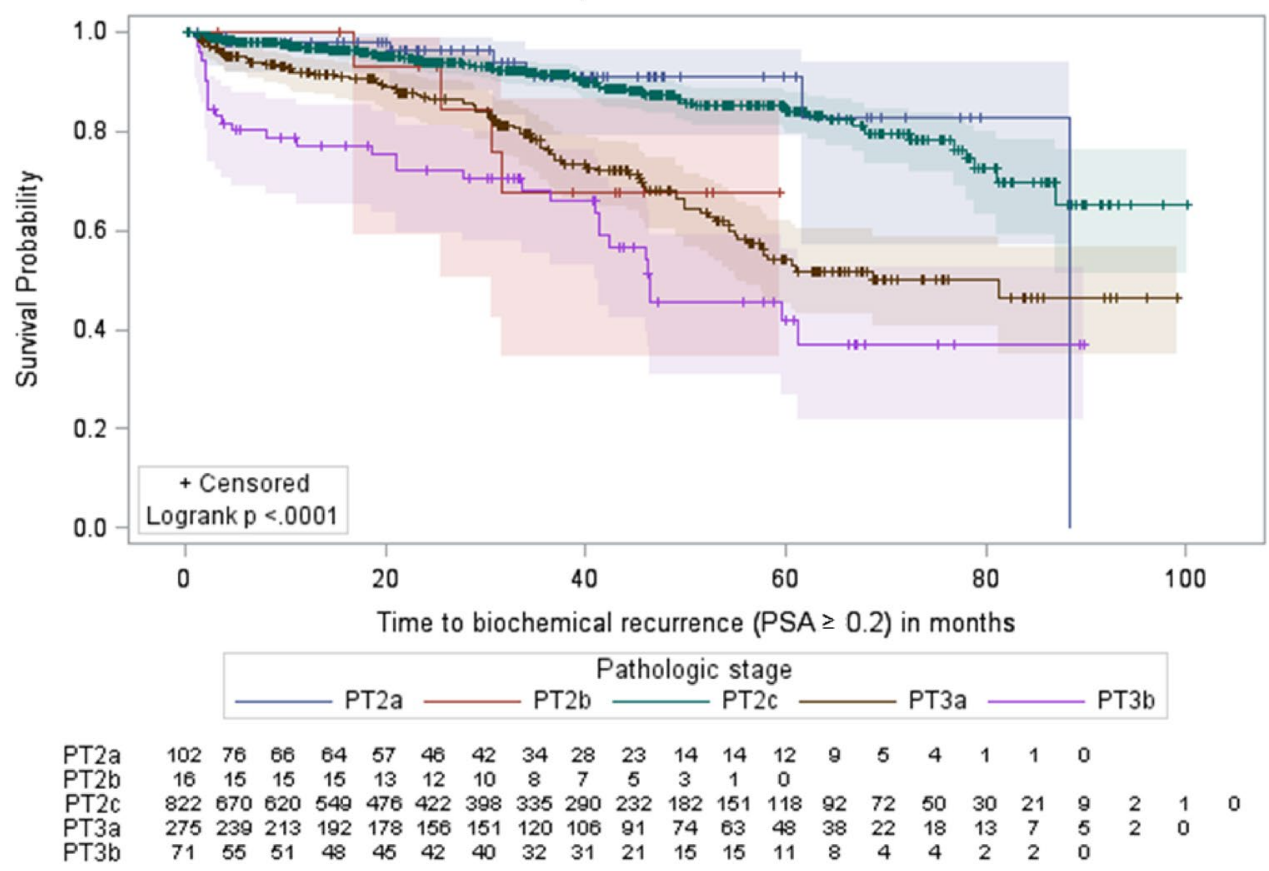

Biochemical recurrence (BCR) free survival according to pathologic stage

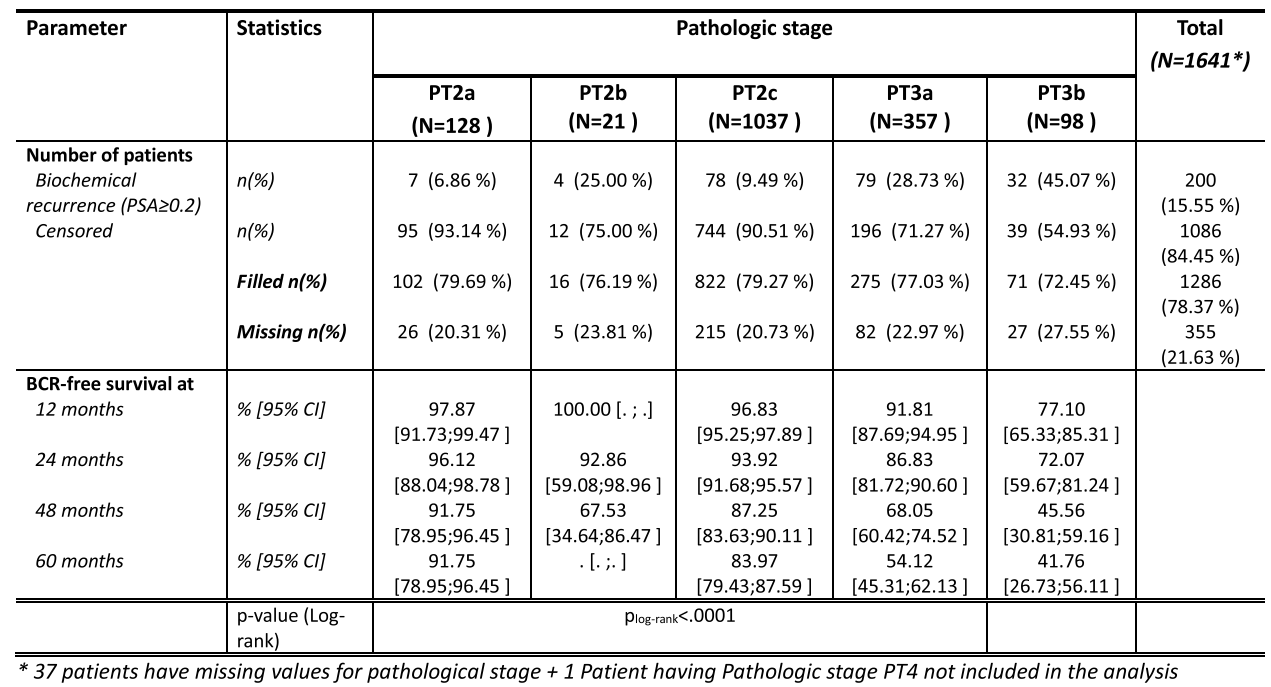


Fig. 6 Biochemical progression-free survival according to pathologic stage and surgical margins
Product-Limit Survival Estimates

With Number of Subjects at Risk and 95\% Confidence Limits

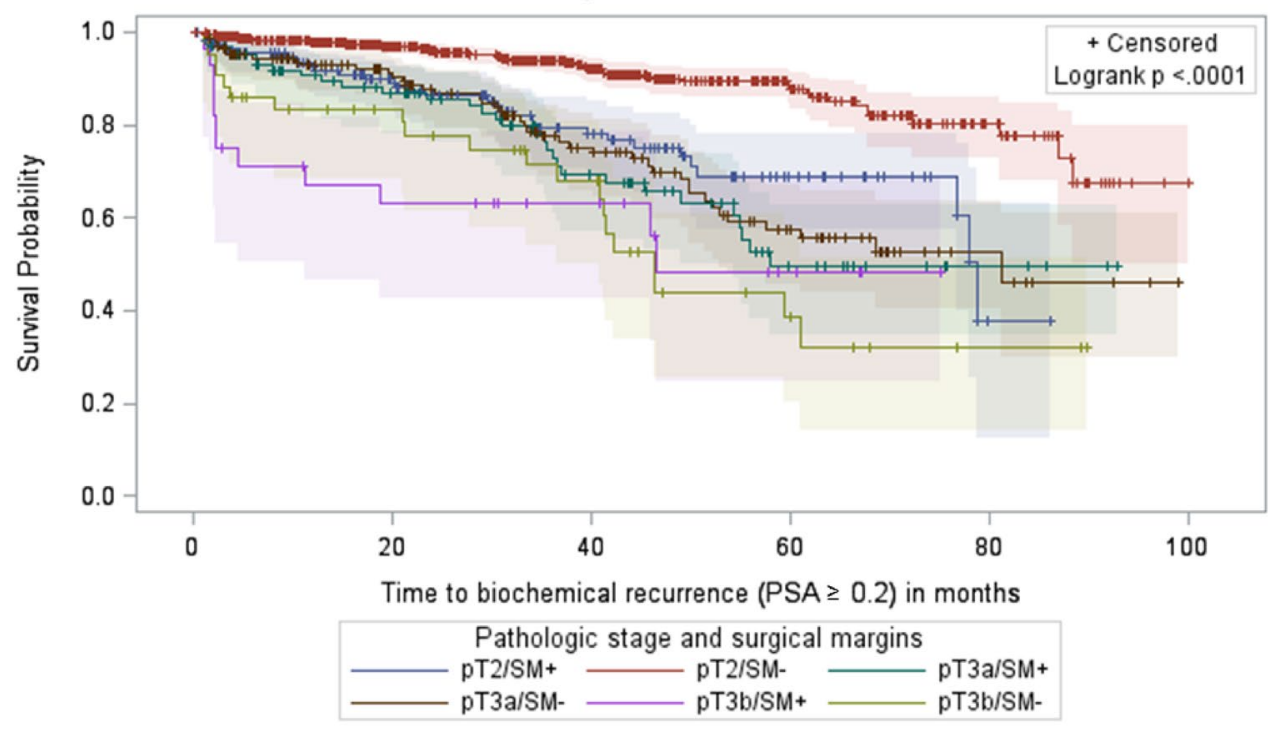
$\begin{array}{llllllllllllllllllllll}165 & 132 & 124 & 111 & 99 & 87 & 81 & 61 & 57 & 48 & 34 & 29 & 22 & 17 & 12 & 8 & 1 & 1 & 0 & & \\ 772 & 626 & 574 & 515 & 446 & 393 & 369 & 316 & 268 & 212 & 165 & 137 & 108 & 84 & 65 & 46 & 30 & 21 & 9 & 2 & 1 & 0 \\ 103 & 91 & 77 & 72 & 68 & 59 & 57 & 46 & 39 & 34 & 27 & 22 & 15 & 13 & 7 & 6 & 4 & 3 & 2 & 0 & & \\ 164 & 140 & 129 & 114 & 104 & 92 & 89 & 69 & 62 & 52 & 43 & 37 & 31 & 24 & 14 & 11 & 8 & 3 & 3 & 2 & 0 & \end{array}$ $\begin{array}{lllllllllllllllllll}28 & 19 & 19 & 17 & 16 & 16 & 15 & 11 & 11 & 9 & 6 & 6 & 4 & 3 & 1 & 1 & 0 & & \\ 43 & 36 & 32 & 31 & 29 & 26 & 25 & 21 & 20 & 12 & 9 & 9 & 7 & 5 & 3 & 3 & 2 & 2 & 0\end{array}$

Biochemical recurrence (BCR) free survival according to pathologic stage and surgical margins

\begin{tabular}{|c|c|c|c|c|c|c|c|c|}
\hline \multirow[t]{2}{*}{ Parameter } & \multirow[t]{2}{*}{ Statistics } & \multicolumn{6}{|c|}{ Pathologic stage and surgical margins (combinations) } & \multirow{2}{*}{$\begin{array}{c}\text { Total } \\
(N=1630 *\end{array}$} \\
\hline & & $\begin{array}{l}\text { pT2/SM+ } \\
(\mathrm{N}=206)\end{array}$ & $\begin{array}{l}\text { pT2/SM- } \\
(\mathrm{N}=977)\end{array}$ & $\begin{array}{c}\text { pT3a/SM+ } \\
\text { (N=127) }\end{array}$ & $\begin{array}{l}\text { pT3a/SM- } \\
\text { (N=222) }\end{array}$ & $\begin{array}{c}\text { pT3b/SM+ } \\
(\mathrm{N}=38)\end{array}$ & $\begin{array}{c}\text { pT3b/SM- } \\
(\mathrm{N}=60)\end{array}$ & \\
\hline $\begin{array}{l}\text { Number of patients } \\
\text { Biochemical } \\
\text { recurrence } \\
(P S A>=0.2)\end{array}$ & $n(\%)$ & $33(20.00 \%)$ & $55(7.12 \%)$ & $31(30.10 \%)$ & $44(26.83 \%)$ & $12(42.86 \%)$ & $20(46.51 \%)$ & $\begin{array}{c}195 \\
(15.29 \%)\end{array}$ \\
\hline Censored & $\begin{array}{l}n(\%) \\
\text { Filled } n(\%) \\
\text { Missing } n(\%)\end{array}$ & $\begin{array}{c}132(80.00 \%) \\
165(80.10 \%) \\
41(19.90 \%)\end{array}$ & $\begin{array}{l}717(92.88 \%) \\
772(79.02 \%) \\
205(20.98 \%)\end{array}$ & $\begin{array}{l}72(69.90 \%) \\
103(81.10 \%) \\
24(18.90 \%)\end{array}$ & $\begin{array}{l}120(73.17 \%) \\
164(73.87 \%) \\
58(26.13 \%)\end{array}$ & $\begin{array}{l}16(57.14 \%) \\
28(73.68 \%) \\
10(26.32 \%)\end{array}$ & $\begin{array}{l}23(53.49 \%) \\
43(71.67 \%) \\
17(28.33 \%)\end{array}$ & $\begin{array}{c}1080 \\
(84.71 \%) \\
1275 \\
(78.22 \%) \\
355 \\
(21.78 \%)\end{array}$ \\
\hline BCR-free survival at & & & & & & & & \\
\hline 12 months & $\%[95 \% \mathrm{Cl}]$ & $\begin{array}{c}92.52 \\
{[86.84 ; 95.80]}\end{array}$ & $\begin{array}{c}97.95 \\
{[96.55 ; 98.78]}\end{array}$ & $\begin{array}{c}90.61 \\
{[82.69 ; 95.02]}\end{array}$ & $\begin{array}{c}92.87 \\
{[87.46 ; 96.00]}\end{array}$ & $\begin{array}{c}67.29 \\
{[46.46 ; 81.49]}\end{array}$ & $\begin{array}{c}83.52 \\
{[68.48 ; 91.79]}\end{array}$ & \\
\hline 24 months & $\%[95 \% \mathrm{Cl}]$ & $\begin{array}{c}86.31 \\
{[78.98 ; 91.22]}\end{array}$ & $\begin{array}{c}96.04 \\
{[94.05 ; 97.38]}\end{array}$ & $\begin{array}{c}85.52 \\
{[76.24 ; 91.38]}\end{array}$ & $\begin{array}{c}87.65 \\
{[80.74 ; 92.20]}\end{array}$ & $\begin{array}{c}63.33 \\
{[42.46 ; 78.39]}\end{array}$ & $\begin{array}{c}77.76 \\
{[61.41 ; 87.83]}\end{array}$ & \\
\hline 48 months & $\%[95 \% \mathrm{Cl}]$ & $\begin{array}{c}75.20 \\
{[65.30 ; 82.65]}\end{array}$ & $\begin{array}{c}90.05 \\
{[86.49 ; 92.71]}\end{array}$ & $\begin{array}{c}65.69 \\
{[52.93 ; 75.76]}\end{array}$ & $\begin{array}{c}69.78 \\
{[59.59 ; 77.87]}\end{array}$ & $\begin{array}{c}48.25 \\
{[24.61 ; 68.47]}\end{array}$ & $\begin{array}{c}44.05 \\
{[25.47 ; 61.18]}\end{array}$ & \\
\hline 60 months & $\%[95 \% \mathrm{Cl}]$ & $\begin{array}{c}69.04 \\
{[57.37 ; 78.11]}\end{array}$ & $\begin{array}{c}87.92 \\
{[83.46 ; 91.25]}\end{array}$ & $\begin{array}{c}49.68 \\
{[34.91 ; 62.81]}\end{array}$ & $\begin{array}{c}57.40 \\
{[45.84 ; 67.35]}\end{array}$ & $\begin{array}{c}48.25 \\
{[24.61 ; 68.47]}\end{array}$ & $\begin{array}{c}38.55 \\
{[20.16 ; 56.70]}\end{array}$ & \\
\hline & $\begin{array}{l}\text { p-value (Log- } \\
\text { rank) }\end{array}$ & \multicolumn{4}{|c|}{$p_{\text {log } \text {-rank }}=0.0000$} & & & \\
\hline
\end{tabular}


Table 5 Univariate analysis for different variables for prediction of positive surgical margins

\begin{tabular}{|c|c|c|c|}
\hline & PSM & Negative SM & $\mathrm{p}$ \\
\hline Prostate weight (n, mean, sd) & $368,39.7(16.2)$ & $1273,45.7(18.9)$ & $<0.0001^{*}$ \\
\hline Preoperative PSA n (\%) & & & $0.01^{\wedge}$ \\
\hline$<10 \mathrm{ng} / \mathrm{ml}$ & $230(21.4)$ & 847 (78.6) & \\
\hline$>=10 \mathrm{ng} / \mathrm{ml}$ & $66(29.1)$ & $161(70.9)$ & \\
\hline Preoperative Gleason score $\mathrm{n}(\%)$ & & & $0.02^{\wedge}$ \\
\hline$<7$ & $216(21.4)$ & 793 (78.6) & \\
\hline$=7$ & $87(29.4)$ & 209 (70.6) & \\
\hline$>7$ & $7(16.3)$ & $36(83.7)$ & \\
\hline Previous Prostate surgery n $(\%)$ & & & $0.76^{\wedge}$ \\
\hline No & $359(22.9)$ & $1210(77.1)$ & \\
\hline Yes & $9(20.9)$ & $34(79.1)$ & \\
\hline Previous abdominal surgery $\mathrm{n}(\%)$ & & & $0.64^{\wedge}$ \\
\hline No & $237(23.1)$ & 788 (76.9) & \\
\hline Yes & $134(22.1)$ & $472(77.9)$ & \\
\hline Pathologic stage $\mathrm{n}(\%)$ & & & $<0.0001^{\wedge}$ \\
\hline $\mathrm{pT} 2 \mathrm{a}$ & $12(9.4)$ & $116(90.6)$ & \\
\hline pT2b & $2(9.5)$ & $19(90.5)$ & \\
\hline pT2c & $192(18.6)$ & $842(81.4)$ & \\
\hline pT3a & $127(36.4)$ & $222(63.6)$ & \\
\hline pT3b & $38(38.7)$ & $60(61.3)$ & \\
\hline Pathologic Gleason score n (\%) & & & $<0.0001^{\wedge}$ \\
\hline$<7$ & $96(13.9)$ & $593(86.1)$ & \\
\hline$=7$ & $247(28.3)$ & $625(71.7)$ & \\
\hline$>7$ & $28(35)$ & $52(65)$ & \\
\hline Type of neurovascular tissue dissection $\mathrm{n}(\%)$ & & & $0.68^{\wedge}$ \\
\hline Extra & $1(11.1)$ & $8(88.9)$ & \\
\hline Inter & $258(22.5)$ & $887(77.5)$ & \\
\hline Intra & $31(23.7)$ & $100(76.3)$ & \\
\hline Conservation of the tip of the seminal vesicles $\mathrm{n}(\%)$ & & & $0.35^{\wedge}$ \\
\hline No & $254(23.4)$ & $833(76.6)$ & \\
\hline Yes & $119(21.3)$ & 439 (78.7) & \\
\hline Surgeon's volume n(\%) & & & $0.02^{\wedge}$ \\
\hline$>200 /$ year & $187(21.8)$ & $672(78.2)$ & \\
\hline 100-200/year & $70(19.1)$ & $296(80.9)$ & \\
\hline$<100 /$ year & $118(27.3)$ & $314(72.7)$ & \\
\hline
\end{tabular}

Variables with a $\mathrm{p}$ value $<0.10$ at the univariable analysis, were considered in the multivariable model. PSM positive surgical margins, SM surgical margins, $P S A$ prostate-specific antigen

*T test; ${ }^{\wedge}$ Chi-square or Fisher exact test 
Table 6 Multivariate Cox proportional hazard model for different variables for prediction of positive surgical margins

\begin{tabular}{llll}
\hline Variable & Risk ratio & $95 \%$ CI & P value \\
\hline PSA $<10 \mathrm{ng} / \mathrm{ml}$ & 1 & & \\
PSA $\geq 10 \mathrm{ng} / \mathrm{ml}$ & 1.48 & $1-2.17$ & 0.04 \\
Gleason score $<7$ & 1 & & \\
Gleason score $=7$ & 1.28 & $0.52-1.80$ & 0.27 \\
Gleason score $>7$ & 1.78 & $0.84-1.93$ & 0.03 \\
Pathologic stage pT2a & 1 & & \\
pT3a & 3.14 & $1.52-6.48$ & 0.002 \\
pT3b & 2.83 & $1.2-6.68$ & 0.01 \\
Pathologic Gleason score $<7$ & 1 & & \\
$=7$ & 1.45 & $0.85-2.46$ & 0.17 \\
$>7$ & 1.84 & $1.24-2.48$ & 0.001 \\
Surgeon's volume $>200$ cases/year & 1 & & \\
$<100$ & 1.41 & $1.01-1.98$ & 0.04 \\
$100-200$ & 0.70 & $0.49-1.03$ & 0.07 \\
\hline
\end{tabular}

Table 7 Univariate analysis for different variables for prediction of biochemical recurrence

\begin{tabular}{|c|c|c|c|c|c|}
\hline & \multicolumn{2}{|c|}{ No BCR } & \multicolumn{2}{|c|}{ BCR } & \multirow[t]{2}{*}{$\mathrm{p}^{\wedge}$} \\
\hline & $\mathrm{n}$ & $\%$ & $\mathrm{~N}$ & $\%$ & \\
\hline \multicolumn{5}{|c|}{ Positive surgical margins } & $<0.0001$ \\
\hline No & 750 & 76.5 & 230 & 23.5 & \\
\hline Yes & 167 & 56.4 & 129 & 43.6 & \\
\hline \multicolumn{5}{|c|}{ Pathologic stage } & $<0.0001$ \\
\hline pT2a & 83 & 83 & 17 & 17 & \\
\hline pT2b & 12 & 75 & 4 & 25 & \\
\hline pT2c & 640 & 79.1 & 169 & 20.9 & \\
\hline pT3a & 149 & 54.8 & 123 & 45.2 & \\
\hline pT3b & 25 & 35.7 & 45 & 64.3 & \\
\hline \multicolumn{5}{|c|}{ Pathologic Gleason score } & $<0.0001$ \\
\hline$<7$ & 426 & 79.9 & 107 & 20.1 & \\
\hline$=7$ & 463 & 67.6 & 222 & 32.4 & \\
\hline$>7$ & 22 & 39.3 & 34 & 60.7 & \\
\hline \multicolumn{5}{|c|}{ Prostate capsule infraction } & $<0.0001$ \\
\hline No & 805 & 73.9 & 284 & 26.1 & \\
\hline Yes & 87 & 56.9 & 66 & 43.1 & \\
\hline \multicolumn{5}{|c|}{ Conservation of the tip of the seminal vesicles } & $<0.0001$ \\
\hline No & 635 & 68.6 & 291 & 31.4 & \\
\hline Yes & 284 & 79.6 & 73 & 20.4 & \\
\hline \multicolumn{5}{|c|}{ Type of neurovascular bundle dissection } & 0.88 \\
\hline Extra & 3 & 75 & 1 & 25 & \\
\hline Inter & 604 & 69 & 271 & 31 & \\
\hline Intra & 81 & 71 & 33 & 29 & \\
\hline
\end{tabular}

$B C R$ biochemical recurrence

${ }^{\wedge}$ Chi-square test
Table 8 Multivariate Cox proportional hazard model for different variables for prediction of biochemical recurrence

\begin{tabular}{llll}
\hline Variable & Risk ratio & $95 \%$ CI & P value \\
\hline Negative surgical margins & 1 & & \\
Positive surgical margins & 1.86 & $1.35-2.58$ & 0.0001 \\
Pathologic stage pT2a & 1 & & \\
$\quad$ pT3a & 2.86 & $1.51-5-43$ & 0.0012 \\
pT3b & 4.69 & $2.03-10.85$ & 0.0003 \\
Pathologic Gleason score $<7$ & 1 & & \\
$=7$ & 2.05 & $1.29-3.25$ & 0.002 \\
$>7$ & 3.3 & $1.67-6.55$ & 0.0006 \\
Conservation of the tip of the & 1 & & \\
$\quad$ seminal vesicles & & & \\
$\quad$ No conservation & 1.59 & $1.15-2.18$ & 0.004 \\
Capsule infraction & 1 & & \\
Non-capsular infraction & 0.91 & $0.6-1.39$ & 0.67 \\
\hline
\end{tabular}

experience even with different approaches in RP (open/laparoscopic) in obtaining high-quality oncologic outcomes.

Funding Open access funding provided by Università degli Studi di Roma Tor Vergata within the CRUI-CARE Agreement..

\section{Compliance with ethical standards}

Disclosures Drs Anastasios D. Asimakopoulos, Filippo Annino, Camille Mugnier, Laurent Lopez, Jean Luc Hoepffner, Richard Gaston and Thierry Piechaud have no conflicts of interest or financial ties to disclose.

Open Access This article is licensed under a Creative Commons Attribution 4.0 International License, which permits use, sharing, adaptation, distribution and reproduction in any medium or format, as long as you give appropriate credit to the original author(s) and the source, provide a link to the Creative Commons licence, and indicate if changes were made. The images or other third party material in this article are included in the article's Creative Commons licence, unless indicated otherwise in a credit line to the material. If material is not included in the article's Creative Commons licence and your intended use is not permitted by statutory regulation or exceeds the permitted use, you will need to obtain permission directly from the copyright holder. To view a copy of this licence, visit http://creativecommons.org/licenses/by/4.0/.

\section{References}

1. Hamdy FC, Donovan JL, Lane JA, Mason M, Metcalfe C, Holding P, Davis M, Peters TJ, Turner EL, Martin RM, Oxley J, Robinson M, Staffurth J, Walsh E, Bollina P, Catto J, Doble A, Doherty A, Gillatt D, Kockelbergh R, Kynaston H, Paul A, Powell P, Prescott S, Rosario DJ, Rowe E, Neal DE (2016) ProtecT Study Group 10-Year Outcomes after Monitoring, Surgery, or Radiotherapy for Localized Prostate Cancer. N Engl J Med 375:1415-1424

2. Takenaka A, Ak T (2012) Anatomical basis for carrying out a state-of-the-art radical prostatectomy. Int J Urol 19(1):7-19 
3. Isbarn H, Wanner M, Salomon G, Steuber T, Schlomm T, Köllermann J, Sauter G, Haese A, Heinzer H, Huland H, Graefen M (2010) Long-term data on the survival of patients with prostate cancer treated with radical prostatectomy in the prostate-specific antigen era. BJU Int 106(1):37-43

4. Pisansky TM, Thompson IM, Valicenti RK, D’Amico AV, Selvarajah S (2019) Adjuvant and Salvage Radiotherapy after Prostatectomy: ASTRO/AUA Guideline Amendment 2018-2019. J Urol 202(3):533-538

5. Hashimoto T, Yoshioka K, Horiguchi Y, Inoue R, Yoshio O, Nakashima J, Tachibana M (2015) Clinical effect of a positive surgical margin without extraprostatic extension after robot-assisted radical prostatectomy. Urol Oncol 33(12):503.e1-6

6. Sammon JD, Trinh QD, Sukumar S, Ravi P, Friedman A, Sun M, Schmitges J, Jeldres C, Jeong W, Mander N, Peabody JO, Karakiewicz PI, Harris M (2013) Risk factors for biochemical recurrence following radical perineal prostatectomy in a large contemporary series: a detailed assessment of margin extent and location. Urol Oncol 31(8):1470-1476

7. Sooriakumaran P, Haendler L, Nyberg T, Gronberg H, Nilsson A, Carlsson S, Hosseini A, Adding C, Jonsson M, Ploumidis A, Egevad L, Steineck G, Wiklund P (2012) Biochemical recurrence after robot-assisted radical prostatectomy in a European singlecentre cohort with a minimum follow-up time of 5 years. Eur Urol 62(5):768-774

8. Simon RM, Howard LE, Freedland SJ, Aronson WJ, Terris MK, Kane CJ, Amling CL, Cooperberg MR, Vidal AC (2016) Adverse pathology and undetectable ultrasensitive prostate-specific antigen after radical prostatectomy: is adjuvant radiation warranted? BJU Int 117(6):897-903

9. Touijer KA, Mazzola CR, Sjoberg DD, Scardino PT, Eastham JA (2014) Long-term outcomes of patients with lymph node metastasis treated with radical prostatectomy without adjuvant androgendeprivation therapy. Eur Urol 65(1):20-25

10. Fairey AS, Daneshmand S, Skinner EC, Schuckman A, Cai J, Lieskovsky G (2014) Long-term cancer control after radical prostatectomy and bilateral pelvic lymph node dissection for pT3bN0M0 prostate cancer in the prostate-specific antigen era. Urol Oncol 32(2):85-91

11. Dindo D, Demartines N, Clavien PA (2004) Classification of surgical complications: a new proposal with evaluation in a cohort of 6336 patients and results of a survey. Ann Surg 240:205-213

12. Asimakopoulos AD, Annino F, D'Orazio A, Pereira CF, Mugnier C, Hoepffner JL, Piechaud T, Gaston R (2010) Complete periprostatic anatomy preservation during robot-assisted laparoscopic radical prostatectomy (RALP): the new pubovesical complex-sparing technique. Eur Urol 58(3):407-417

13. Amling CL, Bergstralh EJ, Blute ML, Slezak JM, Zincke H (2001) Defining prostate specific antigen progression after radical prostatectomy: what is the most appropriate cut point? J Urol 165:1146-1151

14. Olde Heuvel J, de Wit-van der Veen BJ, Huizing DMV, van der Poel HG, van Leeuwen PJ, Bhairosing PA, Stokkel MPM, Slump CH. (2020) State-of-the-art Intraoperative Imaging Technologies for Prostate Margin Assessment: A Systematic Review. Eur Urol Focus. https://doi.org/10.1016/j.euf.2020.02.004

15. Novara G, Ficarra V, Mocellin S, Ahlering TE, Carroll PR, Graefen M, Guazzoni G, Menon M, Patel VR, Shariat SF, Tewari AK, Van Poppel H, Zattoni F, Montorsi F, Mottrie A, Rosen RC, Wilson TG (2012) Systematic review and meta-analysis of studies reporting oncologic outcome after robot-assisted radical prostatectomy. Eur Urol 62(3):382-404
16. Ficarra V, Novara G, Secco S, D’Elia C, Boscolo-Berto R, Gardiman M, Cavalleri S, Artibani W (2009) Predictors of positive surgical margins after laparoscopic robot assisted radical prostatectomy. J Urol 182(6):2682-2688

17. Patel VR, Coelho RF, Rocco B, Orvieto M, Sivaraman A, Palmer KJ, Kameh D, Santoro L, Coughlin GD, Liss M, Jeong W, Malcolm J, Stern JM, Sharma S, Zorn KC, Shikanov S, Shalhav AL, Zagaja GP, Ahlering TE, Rha KH, Albala DM, Fabrizio MD, Lee DI, Chauhan S (2011) Positive surgical margins after robotic assisted radical prostatectomy: a multi-institutional study. J Urol 186(2):511-516

18. Badani KK, Kaul S, Menon M (2007) Evolution of robotic radical prostatectomy: assessment after 2766 procedures. Cancer 110:1951-1958

19. Menon M, Bhandari M, Gupta N, Lane Z, Peabody JO, Rogers CG, Sammon J, Siddiqui SA, Diaz M (2010) Biochemical recurrence following robot-assisted radical prostatectomy: analysis of 1384 patients with a median 5-year follow-up. Eur Urol 58:838-846

20. Sukumar S, Rogers CG, Trinh QD, Sammon J, Sood A, Stricker H, Peabody JO, Menon M, Diaz-Insua M (2014) Oncological outcomes after robot-assisted radical prostatectomy: long-term follow-up in 4803 patients. BJU Int 114(6):824-831

21. Murphy DG, Kerger M, Crowe H, Peters JS, Costello AJ (2009) Operative details and oncological and functional outcome of robotic-assisted laparoscopic radical prostatectomy: 400 cases with a minimum of 12 months follow-up. Eur Urol 55:1358-1366

22. Suardi N, Ficarra V, Willemsen P, De Wil P, Gallina A, De Naeyer G, Schatteman P, Montorsi F, Carpentier P, Mottrie A (2012) Long-term Biochemical Recurrence Rates After Robotassisted Radical Prostatectomy: analysis of a Single-center Series of Patients With a Minimum Follow-up of 5 Years. Urology 79:133-138

23. Liss MA, Lusch A, Morales B, Beheshti N, Skarecky D, Narula N, Osann K, Ahlering TE (2012) Robot-assisted radical prostatectomy: 5-year oncological and biochemical outcomes. J Urol 188:2205-2210

24. Diaz M, Peabody JO, Kapoor V, Sammon J, Rogers CG, Stricker H, Lane Z, Gupta N, Bhandari M, Menon M (2015) Oncologic outcomes at 10 years following robotic radical prostatectomy. Eur Urol 67(6): 1168-1176

25. Bravi CA, Tin A, Vertosick E, Mazzone E, Martini A, Dell'Oglio P, Stabile A, Gandaglia G, Fossati N, Suardi N, Gallina A, Briganti A, Montorsi F, Vickers A (2019) The Impact of Experience on the Risk of Surgical Margins and Biochemical Recurrence after Robot-Assisted Radical Prostatectomy: A Learning Curve Study. J Urol 202(1):108-113

26. Wirth MP, Froehner M (2010) Radical prostatectomy-only centers: the future in genitourinary surgery? Eur Urol 57(6):953-954

27. Tewari AK, Patel ND, Leung RA, Yadav R, Vaughan ED, ElDouaihy Y, Tu JJ, Amin MB, Akhtar M, Burns M, Kreaden U, Rubin MA, Takenaka A, Shevchuk MM (2010) Visual cues as a surrogate for tactile feedback during robotic-assisted laparoscopic prostatectomy: posterolateral margin rates in 1340 consecutive patients. BJU Int. 106(4):528-536

28. Gilbert SM, Dunn RL, Miller DC, Montgomery JS, Skolarus TA, Weizer AZ, Wood DP Jr, Hollenbeck BK (2017) Functional Outcomes Following Nerve Sparing Prostatectomy Augmented with Seminal Vesicle Sparing Compared to Standard Nerve Sparing Prostatectomy: Results from a Randomized Controlled Trial. J Urol 198(3):600-607 
29. Nguyen LN, Head L, Witiuk K, Punjani N, Mallick R, Cnossen S, Fergusson DA, Cagiannos I, Lavallée LT, Morash C, Breau RH (2017) The Risks and Benefits of Cavernous Neurovascular Bundle Sparing during Radical Prostatectomy: A Systematic Review and Meta-Analysis. J Urol 198(4):760-769

30. Wang X, Wu Y, Guo J, Chen H, Weng X, Liu X (2019) Oncological safety of intrafascial nerve-sparing radical prostatectomy compared with conventional process: a pooled review and meta-regression analysis based on available studies. BMC Urol 19(1):41

Publisher's Note Springer Nature remains neutral with regard to jurisdictional claims in published maps and institutional affiliations. 